\title{
鋼片中心部の偏析拡散に及ぼす圧延条件の影響
}

\author{
勝村＼cjkstart龍郎* 太田 裕樹*

\section{Influence of Rolling Conditions on Reduction of Center Segregation of Steel Ingot}

\author{
Tatsuro KATSUMURA* and Hiroki OTA*
}

(Received on July 20, 2018)

\begin{abstract}
Macroscopic segregation occurs easily at the center of materials with large cross-sectional areas, such as blooms, billets, and ingots. Segregation affects the workability and certain other properties such as mechanical strength and corrosion resistance through phase transformation. Therefore, it is important to manufacture homogeneous materials by eliminating segregation. In this study, the influence of manufacturing conditions on the diffusion of segregation is examined. It was found that the diffusive behavior of some elements in the segregation part depended on the rolling ratio, which is defined as the ratio of the areas of the cast material and the rolled material. And it was possible to estimate diffusive behavior using a parameter including $\mathrm{Ld} / \mathrm{Hm}$, where $\mathrm{Ld}$ is the contact length and $\mathrm{Hm}$ is the mean thickness before and after rolling. In addition, from a comparison of conventional and heavy reduction rolling conditions, we suggested that the recrystallization affected the segregation diffusion behavior.
\end{abstract}

Key words: rolling, material, ingot rolling, steel, segregation, stress field, grooved roll, heavy reduction.

\section{1. 緒 言}

鉄鋼材料は組成ならびに製造条件を種々変化させること で広範囲にわたる強度の付与やミクロ組織の制御により勒 性の確保も可能となり, 多くの特性を得ることができる. このような鉄鋼材料は一般に，インゴット（鋼塊）やスラ ブ, ブルームと呼ばれる比較的断面積の大きい素材として 鋳造を行い, その後, 熱間で圧延を施される. 薄板として 用いられる場合には, さらに冷間圧延を経て最終製品とし て製造されるが，熱間圧延を終えた段階で形鋼や鋼管の中 間素材として用いることも多く，そのため，鋼管など二次 製品の素材としても重要な位置を占める.

圧延により製造される製品・中間素材では鋳造により得 られた大型の鋳片・鋼塊の欠陷が残存寸る可能性がある.

欠陷は，主に材料中心部に鋳造工程で生成した引け巣が未 圧着で残存するポロシティと, 溶鋼が凝固する際に生ずる 濃化部のマクロ的な偏析に大別できる。ポロシティは大型 の鋼片・鋳片を用いると最終凝固時に収縮量が大きくなる ことから残存しやすいが，多くの場合，圧延や鍛造により 小断面化される際の加工度, 寸なわち断面減少率が大きく なることから加工方法やその条件の適正化により欠陥を防 ぐことが可能であるとされる ${ }^{1) \sim 4) . ~}$

一方，素材中心に生ずる偏析は，鋳造中の凝固現象につ いての研究 5),6)から, その生成機構が提案 7),8)されている. 加工に影響を及ぼす素材の偏析はマクロ偏析と称されるも

\footnotetext{
* JFE スチール(株) スチール研究所 テ 470-2322 半田市川崎町 1-1

Steel Research Laboratory, JFE Steel Corporation

1-1 Kawasaki-cho, Handa, Aichi 470-2322, Japan.

E-mail: t-katsumura@jfe-steel.co.jp
}

のが多く, 良く知られている形態として $\mathrm{A}$ 偏析および V 偏 析と呼ばれるものが鋼塊や鋳片に生ずる ${ }^{9)}$.このような偏 析の生成メカニズムとして現在は凝固におけるデンドライ 卜樹間での溶鋼の流動が阻害されて生ずる現象であるとい う考え方が基本になっている. 近年では偏析の数值モデル 化も行われ, 鋼塊の中心偏析の再現などもされつつある ${ }^{10)}$ が，凝固後の偏析部は，粒界偏析あるいは組織変化として その影響が表れる。これらはいずれも加工中には周囲組織 と異なる变形挙動を示すことが多く最終製品に疪を伴う久 陥となり, 本来求められる製品品質を満たすための阻害要 因となり得るため，その抑制技術が検討されている.

この中心偏析のようなマクロ偏析に近い大きな偏析ある いは濃化元素に起因して生じた炭化物などの化合物を拡散 により解消するため, 高炭素軸受鋼を対象に加熱・均熱の

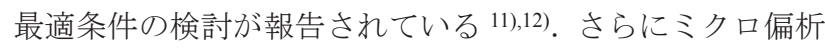
を対象とした場合には非常に長時間かつ高温の熱処理が必 要との報告もある ${ }^{13)}$.また $\mathrm{Al}-\mathrm{Ti}, \mathrm{Al}-\mathrm{Cu}$ および $\mathrm{Al}-\mathrm{Cr}$ 合金 に Ti， V を添加し，熱処理による均質化効果を検討した報 告では, 高温長時間熱処理により偏析組織が拡散するとし

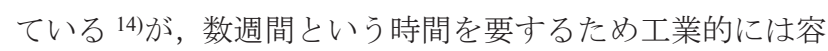
易に適用することは非常に工夫を要する.

他方, 凝固後の固相状態における鋼材中心部の偏析拡散 を加工により行う技術についてはほとんど報告がない。 $\mathrm{Al}-\mathrm{Cu}$ 合金に Ti， V を添加し，そのミクロ偏析と均質化処 理の影響を調查した報告では, $\mathrm{Cu}$ のデンドライトアーム中 心の濃度はやや低温の均質化処理のみでは 100 時間を超え ても完全平衡には至らず, Ti および V は熱処理のみでは, ほとんど均質化されないが強冷間加工を付与することで濃 
度は減少するとしている ${ }^{15)}$. しかしながら加工と均質化処 理の併用でも初期濃度の 3 倍程度は残存するとしているこ とから依然としてミクロ偏析の拡散には課題が多い. 特殊 鋼を用いた拡散焼鈍に関する実験的検討では，バンド状の 偏析が材料中心になるほど強いこと, 均質加熱処理の条件 さらには断面内での偏析に分布があることが報告されてい る ${ }^{16)}$. 特に断面内で偏析に分布が生ずることは加工と偏析 の傾向に関連性があることを示唆しているが, その詳細は 不明なままである。

そこで本報告では偏析の生じやすい大型鋼塊を用い，圧 延条件を変更することで半定量的に偏析抑制に及ぼす効果 を調査し, 拡散挙動のメカニズムについて検討を行った。

\section{2. 実験および解析条件}

\section{1 材料中心偏析の調査}

材料中心の偏析状態は, 所定寸法・成分の鋼塊を圧延す ることによって得た。鋼種は Table 1 に示した代表成分を 有する ASTM-A213 T91 鋼を用いた. 試験鋼塊の寸法は頭 部断面 $710 \times 1120 \mathrm{~mm}$, 底部断面 $620 \times 1050 \mathrm{~mm}$ で高さを $2700 \mathrm{~mm}$ とし, 鋼塊短辺側が $410 \mathrm{~mm}$ 厚になるまで, ロー ル直径が約 $1300 \mathrm{~mm}$ の水平ロールにより圧延した.この後, さらに圧延を行い 2 水準の異なる寸法となる丸断面素材を 作製し, 素材断面積／製品断面積で示される圧下比が異な る素材を得た。ここで素材断面積は試験鋼塊の頭部断面積 を基準として求めた.

偏析の調査には圧延後の素材を使用し, その位置は鋼塊 高さに換算し頭部寄りとした。 その際, 横断面内では最も 偏析が生じやすいと考えられる材料中心部から小型サンプ ル 2 ないし 3 個を採取した。

実製造における鋼塊圧延では一般にユニバーサル圧延法 が用いられる ${ }^{17), 18)}$. これは水平ロールと堅ロールで圧延を 行うものであり, 水平ロールでの圧延により生じた幅広が り部を含め, 幅圧下を竪ロールで圧延するため圧延効率が 良いことが特徵である。一方, 堅ロールの耐荷重はあまり 大きくないことから幅圧下量は小さくなる．このため圧延 途中で鋼塊を圧延方向に垂直な断面内で転回することで水 平ロールにより圧下を行い, 小断面化している. そこでま ずユニバーサル圧延法を模擬した圧延で得られた試験材の 材料中心における圧下比が偏析に及ぼす影響を調查した。

また異なる圧下比での圧延は材料中心の変形, すなわち ひずみが異なるため, 同一圧下比でひずみ履歴が異なる強 圧下法の適用について検討を行った。強圧下法の一例とし て Fig. 1 に示すように, ユニバーサル圧延に対し幅圧下を 小さい孔型が付与された水平ロールで行うことにより強圧 下を行う方法がある。そこで実際の圧延にあたってはこれ を模擬した圧延スケジュールを採用し, その偏析の挙動を 調査した.

Table 1 Chemical composition of tested material ( $\mathrm{wt} \%$ )

\begin{tabular}{|c|c|c|c|c|c|}
\hline Steel & $\mathrm{C}$ & $\mathrm{Si}$ & $\mathrm{Mn}$ & $\mathrm{Cr}$ & $\mathrm{Mo}$ \\
\hline A213-T91 & 0.09 & 0.24 & 0.39 & 8.31 & 0.9 \\
\hline
\end{tabular}
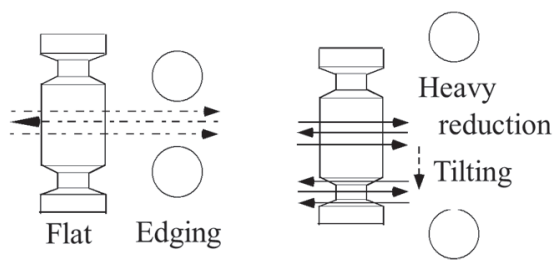

Fig. 1 Example of rolling methods in actual mills; universal rolling (left) and high-lift rolling (right)

\section{2 材料中心におけるひずみ分布}

圧延スケジュールの変更による材料中心のひずみを推定 するため, FEM 解析を行った。解析はラグランジュ未定乗 数法を用いた剛塑性有限要素解析ソルバーCORMILL ${ }^{19)}$ 用いた。鋼塊圧延は圧延パスが多く，全パスの影響を把握 することは困難であること，また偏析の低減には拡散を考 慮した場合，高温であることが望ましいと考えられること から初期圧延段階の影響を調查した。

メッシュは圧延の対称性を考慮して $1 / 4$ 断面とし, この 断面内で圧下方向 10 分割 $\times$ 幅方向 10 分割，長手方向には ロールバイト内を 10 分割程度で入出側に変形域を設け, 8 節点 6 面体アイソパラメトリック低減積分要素による三次 元解析を行った。

変形抵抗は実験に供した素材の単軸圧縮実験結果から井 上 ${ }^{20)}$ ・美坂の式 ${ }^{21)}$ の平均変形抵抗式より求めた流動応力 $\sigma_{e q}$ を与えた。 また温度分布は，以下の方法で採取した結 果から設定した。すなわち実機を用い当該寸法素材を設定 温度にて加熱，1 パス目の圧延前の実測温度であった $1200{ }^{\circ} \mathrm{C}$ おび途中パスの外面温度とそのパス間時間から 熱伝達係数を推定し，そこから得られた各パスの温度降下 量を $5{ }^{\circ} \mathrm{C}$ と平均化して適用した. なお温度分布は 1 次元差 分解析を行い, その結果から内部温度は表層より $100{ }^{\circ} \mathrm{C}$ 高 く設定した．また摩擦係数についてはロールと材料間では クーロン摩擦が生じており摩擦係数值を 0.3 とした。

\section{3. 実験結果}

\section{1 偏析拡散に及ぼす加熱と圧下比の重畳効果}

経験的に知られている加熱・均熱の効果と圧下比の影響 を調查するため，同一寸法の鋼塊を用いた圧延を行った． 圧延は所定の断面を得たパスで一旦停止し，その後，一方 は再加熱を行いさらに小断面となるよう圧下を施し丸断面 形状に成形した。この断面寸法は直径 $210 \mathrm{~mm}$ および 300 $\mathrm{mm}$ であり，鋼塊頭部断面寸法に対する圧下比はそれぞれ 23.0 と 11.3 となる.

これら 2 水準の鋼片について，2.1 節で記述したように 材料中心部からサンプルを複数個採取し，これらに EPMA を適用し， $8 \mathrm{~mm}$ 角の領域を $\mathrm{Cr}, \mathrm{Mo}, \mathrm{S}$ について X 線強度 分布を評価した．その元素面分布図を Fig. 2 に示す. 同図 中，赤色部は強度が大きく，緑など暗色に近づくほど強度 が低いことを示す，この強度の大小は，検量線を介し元素 濃度の高低と一致する。 よって小断面, すなわち圧下比が 大きく, 初期加熱を含め 2 回加熱を行った素材は比較的成 分の偏析が少ない状態であるのに対し, 圧下比が小さく断 面積の大きい素材では $\mathrm{Cr}$, Mo とも，ほぼ同一箇所で濃化 していることが認められた。またその濃化部とほぼ同じ位 
置で $\mathrm{S}$ も濃化していた. このことから圧下比が材料中心の 偏析に影響することが明らかとなった。

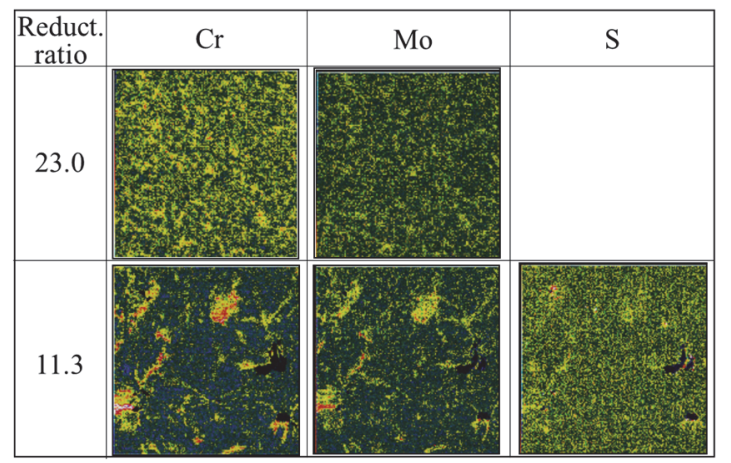

Fig. 2 Distribution of X-ray strength in the cases of lowreduction-ratio and high-reduction-ratio rolling

\section{2 強圧下圧延による偏析拡散の効果}

次に加工条件の相違による偏析拡散効果を調查するため, 強圧下圧延の適用を行った。圧延スケジュールの一部につ いて，その概要を Table 2 に示す. 強圧下圧延の試験にお いては厳密には各パスの圧下率は若干異なるが, Table 2 で はそれを平均し 5 パスごとの区分における各パスの平均圧 下率を記載した。 なおここでは幅方向圧下を示すエッジン グ圧延の圧下量は用いず，主ロールによる圧下方向の圧下 率で整理した。すなおち, 初期厚みである鋼片短辺側の 620 〜 710 $\mathrm{mm}$ 厚から $410 \mathrm{~mm}$ 厚までの平均圧下率を示した.

Table 2 Characteristics of each rolling schedule

\begin{tabular}{|c|c|c|}
\hline \multirow{2}{*}{} & \multicolumn{2}{|c|}{ Mean reduction ratio } \\
\cline { 2 - 3 } & Conventional & Heavy reduct. \\
\hline-5 pass & $2.95 \%$ & $8.19 \%$ \\
\hline-10 pass & $2.37 \%$ & $3.76 \%$ \\
\hline-15 pass & $1.89 \%$ & \\
\hline-20 pass & $2.01 \%$ & \\
\hline
\end{tabular}

従来法では 20 パスまでほぼ同程度の 2～3\%となる圧下 率で圧延を行っている. 他方, 強圧下圧延スケジュールで は初期 5 パスまでの前半部分で強圧下とし，1 パスあたり の圧下率を増加させ 10 パスで圧延を完了させ, 目標厚み の素材を得た。例えば従来圧延スケジュールでは 5 パス後 の目標厚みが $620 \mathrm{~mm}$ であるが, 強圧下圧延スケジュール では $460 \mathrm{~mm}$ である。

この圧延を施した素材軸芯部の $\mathrm{Cr}$ に関し, EPMA 分析 によるX 線強度を比較した。これを Fig. 3 に示す. 同図内 の濃淡比から最終製品の断面積が同一となる圧下比におい ても強圧下圧延を施すことで偏析を軽減できることが認め られた。

\section{3 加熱回数の偏析拡散に及ぼす影響}

3. 2 節の結果は, 強圧下圧延により偏析を低減できるこ とを示したが，偏析拡散に及ぼす加工と加熱による効果の 重畳の寄与は依然として不明瞭である。そこで加熱のみに よる効果を明らかにするため, 同じ圧延パススケジュール を適用し最終断面寸法も同じように作製する過程で，その 全パスを 1 回加熱で行う方法と, 途中パスで再加熱を行う 場合とで比較を行った。最終丸断面寸法は $300 \mathrm{~mm}$ とし,
途中加熱を行う断面目標寸法は $410 \times 830 \mathrm{~mm}$ 程度とした。

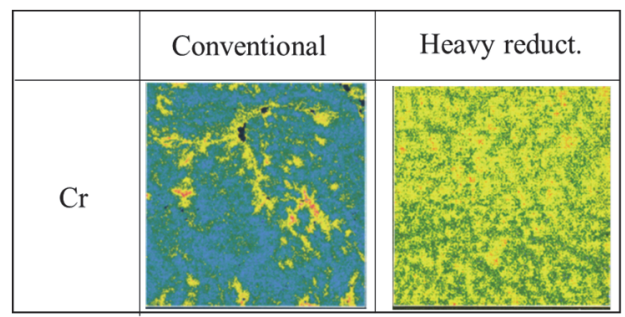

Fig. 3 X-ray strength distribution for conventional rolling schedule and heavy reduction schedule

偏析の評価は EPMA による Crの面分布で行った。これ をFig. 4 に示す. 同図より緑あるいは黄色の濃淡の差異は, 加熱回数が多い条件でより平坦になっている．このことか ら加工中に加熱を行うことで，さらに偏析が低減でき得る ことが示された。

\begin{tabular}{|c|c|c|}
\hline $\begin{array}{c}\text { No. of } \\
\text { heat }\end{array}$ & 1 & 2 \\
\hline $\mathrm{Cr}$ & 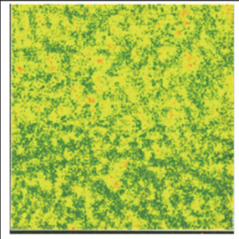 & 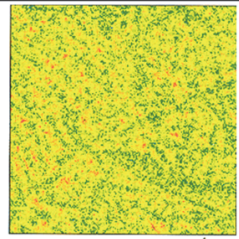 \\
\hline
\end{tabular}

Fig. 4 X-ray strength distribution for different number of heat charges

\section{4. 検 討}

\section{1 偏析の定量評価手法}

3. 3 節に示した加熱回数の変更, すなわち熱履歴変更に より異なる元素強度分布が得られ，偏析低減に有効である という結果を得た。また強圧下では明らかに偏析の低減が 認められた。これらをより定量的に比較するため, EPMA 測定領域 $8 \times 8 \mathrm{~mm}$ の強度分布について Fig. 5 の模式図に示 すように，1)元素量の分布幅，および 2)中心值から一定の 割合の領域を除き元素量が高くなっている濃化面積率, の 2 種を定義し検討を行った。 今回提案した指標は，1)が測定 範囲内の濃度分布のばらつきを，2)が極端な偏析の有無を 評価できるものとして考えた。

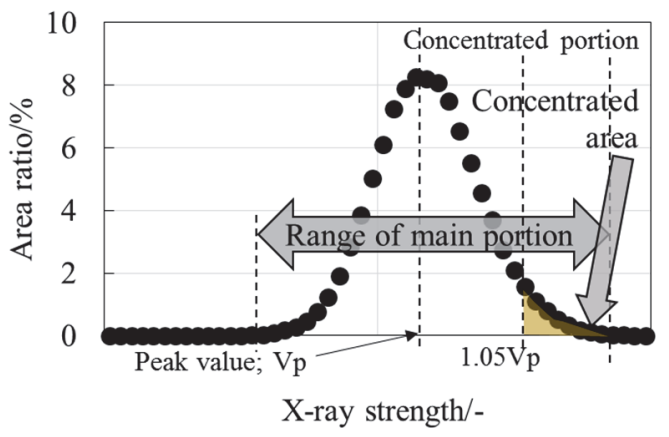

Fig. 5 Definition of parameter used for evaluation of segregation 
なお偏析は微視組織に対して大きく影響を与える。例え ば高温では, 偏析の有無により変態温度が変わるため組織 に相違が生ずることがある，実使用の高温環境における金 属組織への影響等も考慮し, 偏析の濃淡を示す本測定によ る分布幅は 1000 ポイント以下, 強偏析部はより小さい方 が好ましいとして評価した。

\section{2 偏析に及ぼす加熱の効果}

定義した評価法を用い，加熱回数を変更した素材におけ る Cr 偏析を比較した.この結果を Fig. 6 に示す. 同図によ れば強度のバラツキ, すなわち全体的な偏析の分布は 2 回 加熱の方が小さいことがわかる. 他方, 濃化部の面積は 1 回加熱の方が小さい.これらより 2 回加熱法は偏析を抑制・ 均質化できたため, 絶対的な元素分布幅が狭くなり, 濃化 面積がやや大きく評価されたと理解できる。このことは Fig. 3 に示した面分布図からも 2 回加熱材の方が全体に均 一化する傾向であることから明らかである。したがって， ある領域内の面積分率といったマクロ的な評価によれば大 差はないが, 微細組織形成に影響を及ぼすセミマクロ偏析 の観点においては 2 回加熱が有効であると考えられる.

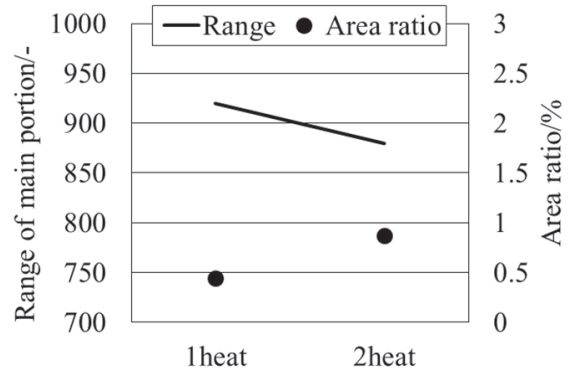

Fig. 6 Segregation of $\mathrm{Cr}$ content against number of heat charges

\section{3 偏析に及ぼす強圧下の効果}

3. 2 節では同じ寸法の素材を用い, 圧下比が同一であっ ても圧延条件の変更により偏析を低減できることがわかっ た. その面分布図から得られた結果に加え, 圧下比を 23 と 大きくし 2 回加熱を適用した，3.1 節に示した，材料の偏 析を EPMA 分析で得た強度分布を用いる本評価法で整理 した. その結果を Fig. 7 に示す. 同図より, 1 回加熱法で も強圧下を行うことにより 2 回加熱で圧下比が大きい結果 とほぼ同等の効果を得られた。また強圧下法は通常圧延条 件に比べ, 濃化を示す面積率が小さく, 全体の分布幅も狭 い.したがって強圧下法は，偏析低減に有効であると考え られる。

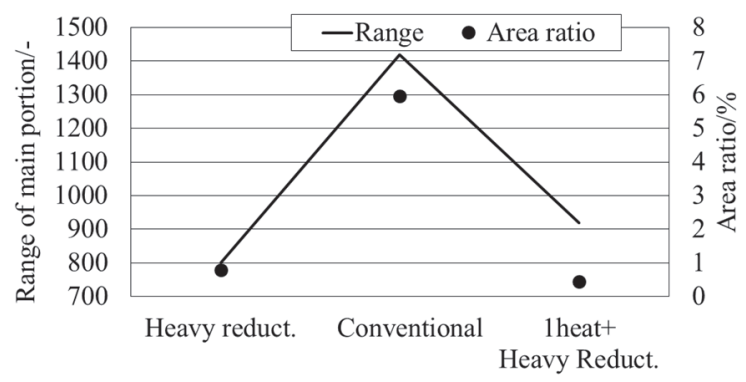

Fig. 7 Segregation of $\mathrm{Cr}$ contents for different rolling schedules

\section{5. 考 察}

\section{1 偏析の熱間加工性に及ぼす影響}

偏析は $\mathrm{Cr}$ や Mo などの濃化現象であり, これを圧延や加 熱条件を変更することにより低減可能であることを説明し た。これらの元素が偏析すると，高温環境下の金属組織が ある温度に対して異なる. Table 1 に示した成分および EPMAにより得られた濃化量として Crのみ $1 \%$ 濃化した成 分を仮定し, 熱力学計算ソフト JMat Pro 10.2 にて高温の相 状態を計算した。これを Fig. 8 に示す.

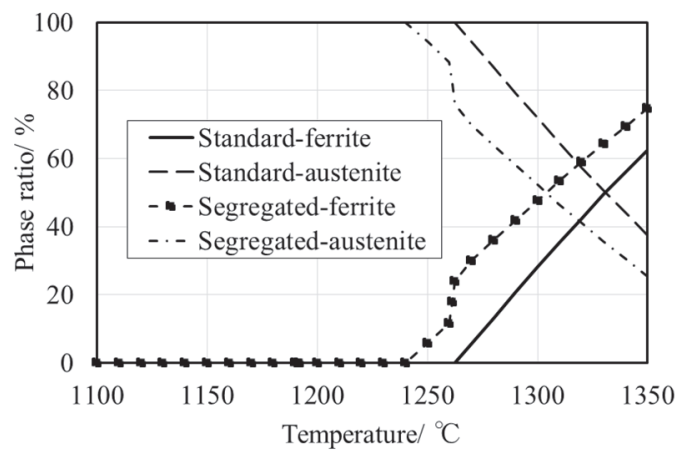

Fig. 8 Relationship between temperature and phase ratio

Cr はフェライト形成元素であることが知られており，こ の濃化により高温のフェライト域が広がり, フェライトか らオーステナイトへの変態温度が偏析の多い成分では低下 したと言える．言い換えれば偏析部においては周囲の組織 に対してフェライトが多くなり，その結果，熱間加工時に は組織差に起因して加工性の劣化を招く。この現象は 13\% $\mathrm{Cr}$ ステンレス鋼の熱間ねじり試験でも報告されている ${ }^{22)}$.

そこで一定の大きさの断面積を有する素材に対しても加 工性を評価可能な手法として，加藤らの提案したテーパビ レット圧延法 ${ }^{23)}$ を用い加工性を調査した。ここで素材寸法 は小径側 $35 \mathrm{~mm}$, 太径側 $43 \mathrm{~mm}$, 長さ $200 \mathrm{~mm}$ とした。 加 工温度 $1250{ }^{\circ} \mathrm{C}$ の限界圧下率を Fig. 9 に示寸。限界圧下率 が高い程，加工性は良好であることから，今回の実験範囲 では偏析の少ない強圧下材は熱間加工性が良好であること を確認した．実際の製造においても偏析に起因した加工性 劣化に伴う現象が強圧下材に比べ従来材では 9 倍の頻度で 生じており，偏析拡散が重要であると考えられる.

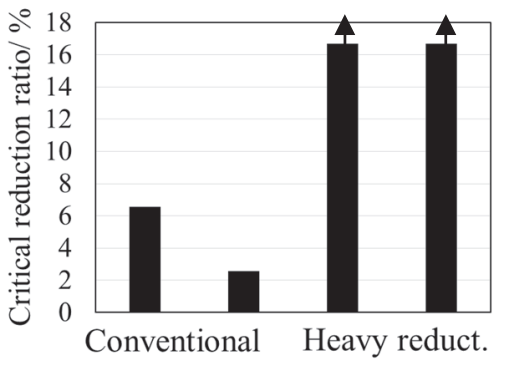

Fig. 9 Critical reduction ratio

\section{2 圧延条件の偏析拡散に与える組織的な影響}

圧延条件の差異について, ロール間隙比 $L d / H m$ を用い, 圧延スケジュールを比較した。この検討にあたっては接触 
弧長 $L d$ をロール半径 $R$ と圧下量 $\Delta h$ の積の平方根, 平均板 厚 $H m$ は（入側板厚 $\times 2+$ 出側板厚） $/ 3$ で与えた. この計 算結果を Fig. 10 に示す.

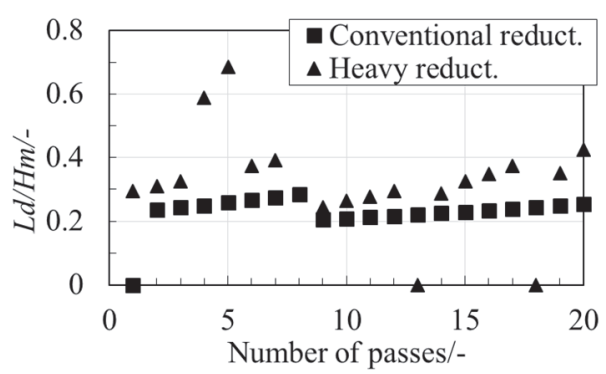

Fig. 10 Difference in roll gap ratio between conventional and heavy reduction schedules

同図より従来圧延法では $0.2 \sim 0.3$ 程度であったロール 間隙比が, 強圧下法の適用により最大で 0.7 となっている ことがわかった. 板厚内部へのひずみの浸透は, 再結晶を 伴う組織微細化を介してせん断帯の関与が推定されてい る ${ }^{24)}$. このせん断帯を有効に利用し, 材料中心での変形を 大きくするには, Hill によるすべり線場解析 25)を工具と材 料の接触長および板厚の比で整理・比較すると, ロールと 素材の接触弧長が板厚と同等もしくはそれ以上である必要 がある．圧下により十分なひずみの浸透効果を得るには， さらに板厚項を小さくする, あるいは強圧下を行うことに よりロール間隙比を大きくすることがせん断帯の傾きをよ

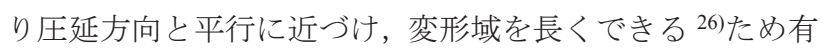
効であると考えられる。また欠陥圧着の視点から，素材表 層の流動応力を内部に比べ高めることで中心へひずみを浸 透させ得るとの報告 27)もある. すなわち偏析の拡散には一 定以上のロール間隙比, 具体的には本材料の断面が大きく 温度分布も付きやすいことを考慮すると今回の条件では 0.5 を超える領域の圧延条件がひずみ浸透に必要であると 考えられる.

\section{3 材料中心のひずみと鋼種による影響の可能性}

そこで次に解析により, ひずみの定量化を図った。ロー ル間隙比の差が大きくなっている圧延前半の条件について FEM 解析により完全に密と仮定した材料中心のひずみを 求めた. 相当塑性ひずみのコンター図を Fig. 11 に, 同図中, 矢印で示した材料中心における最大相当塑性ひずみの比較 を Fig. 12 に示す. ロール間隙比の検討から明らかなよう に，その指標が大きい条件ではひずみがおよそ 0.13 である が, 小さい条件では 0.02 程度とほとんど塑性変形していな いことが認められた.

加工による偏析拡散は加熱による現象とは異なり, 空孔 を介して, あるいは大きな元素であれば加工により生じた 核生成サイトからの再結晶により半ば強制的に拡散が生じ ている ${ }^{28)}$ と推察される。 このモデルによるならば, 強圧下 でひずみを導入し, かつ, やや温度が低下しても加工を加 え続けることでひずみ, すなわち転位が導入されて再結晶 が促進され, その結果として偏析の拡散がなされている可 能性がある。再結晶挙動については, 同じフェライト組織 からなるステンレス鋼である SUS430 鋼について平野らが 検討しており ${ }^{29)}$, ひずみを 0.4 とした場合, $1100{ }^{\circ} \mathrm{C} ゙$ は 10
秒程度のパス間時間で再結晶が生ずると報告している.し かしながら Fig. 10 に示した解析において本条件ではひず みは 0.18 であり SUS430 が再結晶を生ずる 0.4 に対して小 さい值である。
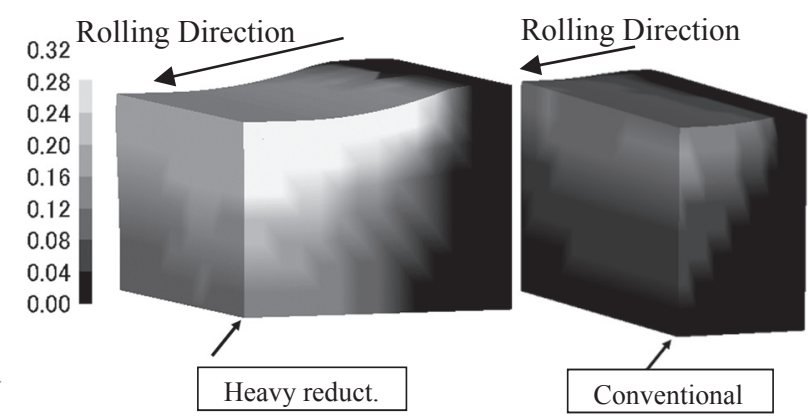

Fig. 11 Analytical results of equivalent plastic strain for heavy reduction (left) and conventional rolling (right) schedule

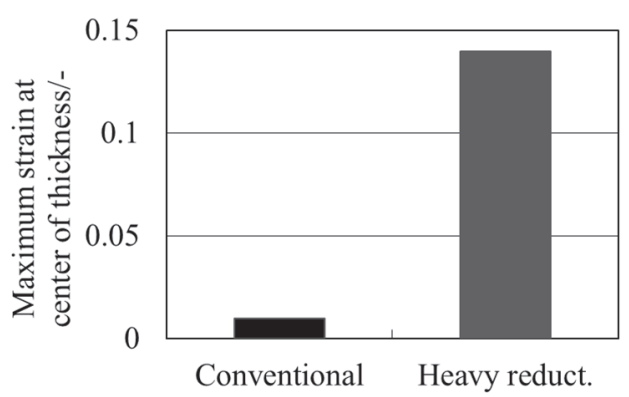

Fig. 12 Maximum equivalent plastic strain at center of thickness for conventional and heavy reduction rolling schedules

そこで本材料の特性を把握するため, 富士電波工機製亚 一メックマスターを用い, 高温環境で単軸圧縮を行った。 試験は直径 $\phi 8 \mathrm{~mm}$, 高さ $12 \mathrm{~mm}$ の円柱試験片を用い, 誘 導加熱により $1250{ }^{\circ} \mathrm{C}$ 加熱, $300 \mathrm{~s}$ の均熱を行った後, 所 定の加工温度まで $4{ }^{\circ} \mathrm{C} / \mathrm{s}$ で降温, 到達して $5 \mathrm{~s}$ 保持後に単 パスあるいは 2 パスの圧縮を実施した。この際，加工する ダイと試験片の摩擦による影響を避けるため, 雲母板をは さんだ。ひずみは単パスの場合， 0.7 程度まで，2 パス加工 の場合は 1 パス目・2 パス目ともひずみを 0.2 とし, 流動応 力曲線を得た。ひずみ速度は本実験の加工条件を考慮し,

1，10 および $40 \mathrm{~s}^{-1}$ にて実施した。

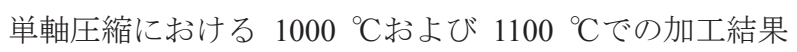
を Fig. 13 に示す. 同図より, 動的回復あるいは動的再結晶 が生じた場合に出現する応力低下は観察されなかった。そ こで回復挙動をさらに詳細に調べるため, 複数回加工を行 った場合の軟化率を調查した。ひずみ速度を $10 / \mathrm{s}$ ，パス間 時間を $1 \mathrm{~s}$ とした時の加工温度と軟化率の関係を Fig. 14 に

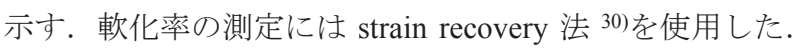

これより A213-T91 材は与えた初期ひずみの 2 パス目にお ける軟化率が小さく, 明らかに回復挙動を示さない傾向に あることがわかった。 寸なわち偏析が残存しや寸い材料中 心に一定のひずみを与えることができれば，蓄積により実 質的なひずみが増加して結晶を生じせしめることを示唆し ており，この挙動が強圧下法に有効に作用したものと思わ 
れる。

以上より強圧下法では圧延初期から材料中心において再 結晶が起こり，そのために偏析も拡散したものと考えられ る.したがって, 偏析拡散は金属学的な変化とも密接に関 係していると推察され, 今後の再結晶挙動と偏析拡散の検 討が必要である.

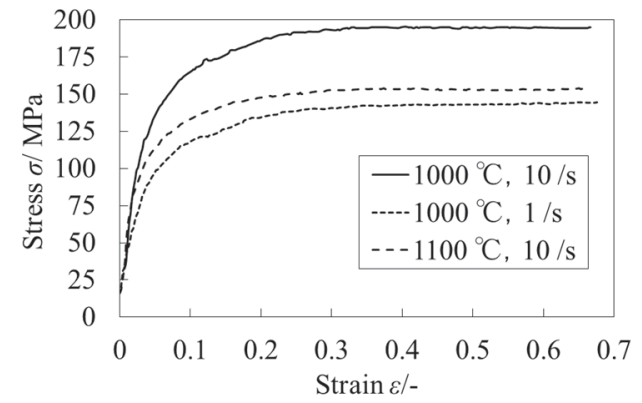

Fig. 13 Flow stress curves at elevated temperature

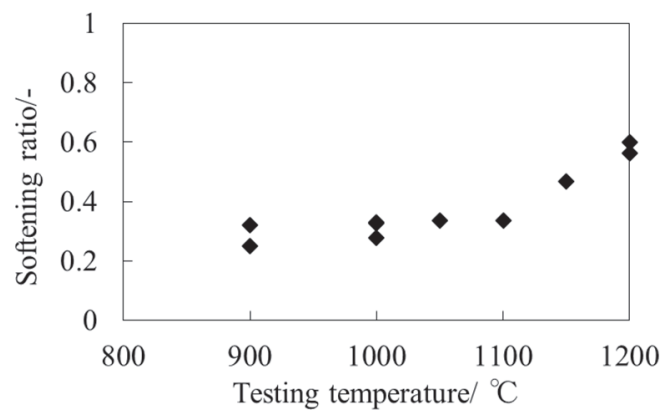

Fig. 14 Temperature dependence of softening ratio

\section{6. 結 言}

大型の試験鋼塊を用い，実現可能な圧延条件で圧下量や 加熱条件を変更することで偏析に及ぼす影響を調査した。 今回の実験範囲で得られた結果を EPMA によって得られ た元素分布, 特に $\mathrm{Cr}$ について偏析部の X 線強度範囲なら びに濃化域面積をパラメータとして整理し, 偏析拡散挙動 のメカニズムについて推察した. 得られた結果は以下の通 りである.

1）鋼塊と製品の断面積比率で示される圧下比を大きく することにより偏析拡散が減少する，加えて強圧下 の適用により偏析は同様に減少する.

2) 強圧下を表現可能なマクロ的な圧延指標であるロー ル間隙比と材料の圧下比を考慮することで偏析拡散 を評価できる.

3）強圧下は材料中心までひずみを浸透させることで再 結晶挙動に影響を及ぼし，これが偏析に関係する可 能性がある。

\section{参 考 文 献}

1) Ståhlberg, U., Keife, H., Lundberg, M. \& Melander, A.: J. Mech. Work. Technol., 4 (1980), 51-63.

2) Nakasaki, M., Takasu, I. \& Utsunomiya, H.: J. Mater.
Process. Technol., 177-1-3 (2006), 521-524.

3) Wang, A., Thomson, P. F. \& Hodgson, P. D.: J. Mater. Process. Technol., 60 (1996), 95-102.

4) Katsumura, T., Iguchi, T., Kimura, H. \& Yanagimoto, J.: Mater. Trans., 55-12 (2014), 1834-1840.

5) Kawawa, T., Sato, H., Miyahara, S., Koyano, T. \& Nemoto, H.: Tetsu-to-Hagané, 60-5 (1974), 486-500.

6) Ogibayashi, S.: Sanyo Tech. Rep., 19-11 (2012), 2-14.

7) Isobe, K.: Tetsu-to-Hagané, 98-8 (2012), 405-414.

8) Miyazaki, M., Isobe, K. \& Murao, T.: Nippon Steel Tech. Rep., 394 (2012), 48-53.

9) Moore, J. J. \& Shah, N. A.: Int. Met. Rev., 28-6 (1983), 338356.

10) Beckermann, C.: Int. Met. Rev., 47-5 (2002), 243-261.

11) Ota, T., Okamoto, K., Nakamura, S. \& Shinko, S.: Tetsu-toHagané, 52-13 (1966), 1851-1859.

12) Kim, K., Park, S. \& Bae, C.: Met. Mater. Int., 20-2 (2014), 207-213.

13) Ward, R. G.: J. Iron Steel Inst., 203 (1965), 930-932.

14) Kamio, A., Tezuka, H., Choi, J. C. \& Takahashi, T.: J. Jpn. Inst. Light Met., 35-5 (1985), 255-260.

15) Kamio, A., Tezuka, H., Choi, J. C. \& Takahashi, T.: J. Jpn. Inst. Light Met., 35-3 (1985), 133-139.

16) Fujiwara, T. \& Obata, E.: Denki-seiko, 33-2 (1962), 106-116.

17) Sakasegawa, K. \& Yamagishi, Y.: Tetsu-to-Hagané, 59-13 (1973), 1643-1667.

18) Kunitomo, T., Hidaka, M., Kobayashi, S., Sakamoto, E. \& Masuyama, Y.: Nippon Kokan Tech. Rep., 74 (1977), 49-58.

19) Yanagimoto, J., Kiuchi, M., Nakamura, M. \& Kurahashi, T.: J. Jpn. Soc. Technol. Plast., 32-367 (1991), 1000-1006.

20) Inouye, K.: Tetsu-to-Hagané, 41-5 (1955), 506-515.

21) Misaka, K. \& Yoshimoto,Y.: J. Jpn. Soc. Technol. Plast., 879 (1967), 414-422.

22) Mimino, T., Kinoshita, K., Hattori, K. \& Matsushita, A.: Tetsu-to-Hagané, 53-7 (1967), 834-837.

23) Kato, K.: Bulletin of Metall. Soc. Osaka Univ., 10 (1969), 46-55.

24) Nakaura, Y., Watanabe, A. \& Ohori, K.: J. Jpn. Inst. Light Met., 57-2 (2007), 67-73.

25) Hill, R.: The mathematical theory of plasticity, (1950), 227228, 256, Oxford University Press.

26) Kasai, D., Komori, A., Ishii, A., Yamada, K. \& Ogawa, S.: Tetsu-to-Hagané, 101-6 (2015), 319-328.

27) Ding, J., Zhao, Z., Jiao, Z. \& Wang, J. : Appl. Thermal Eng., 98 (2016), 29-38.

28) Hotta, S., Murakami, T., Narushima, T., Iguchi, Y. \& Ouchi, C.: ISIJ Int., 45-3 (2005), 338-346.

29) Hirano, N., Fujiwara, M., Yoshida, H. \& Isogawa, S.: Denki Seiko, 76-2 (2005), 87-94.

30) Rao, K. P., Prasad, Y. K. D. V. \& Howbolt, E. B.: J. Mater. Process. Technol., 77-1-3 (1998), 166-174. 